\title{
Contents of Volume 118 (2014)
}

PAGES

Adams, M.J., I. Finkelstein, and D. Ussishkin, The Great Temple of Early Bronze I Megiddo. . . . . . . . . 285-305 Andrews, M.M., A Domus in the Subura of Rome from the Republic Through Late Antiquity . . . . . . . . . . 61-90 Archaeological Institute of America, Awards Presented at the 115th Annual Meeting of the

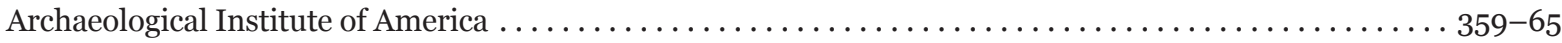

Becker. See Mogetta and Becker.

Blackwell, N.G., Making the Lion Gate Relief at Mycenae: Tool Marks and Foreign Influence . . . . . . . . 451-88 Bridgford. See Molloy et al.

Buxton, B.A., A New Reading of the Belvedere Altar . . . . . . . . . . . . . . . . . . . . . . 91-111 Cadogan, G., Patronage and Prehistory: Recent Publications on the Bronze Age Aegean and Cyprus . . . . . . . 189-95 Carter. See Molloy et al.

Corbett, G.J., D.R. Keller, B.A. Porter, and C.A. Tuttle, Archaeology in Jordan, 2012 and 2013 Seasons . . . . . 627-76 Cosmopoulos, M.B., Cult, Continuity, and Social Memory: Mycenaean Eleusis and the Transition to the

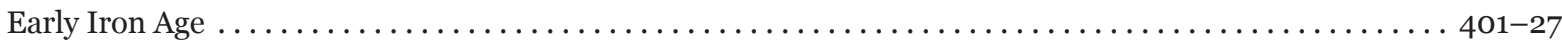

Day. See Molloy et al.

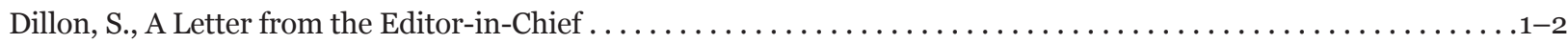

Finkelstein. See Adams et al.

Gaignerot-Driessen, F., Goddesses Refusing to Appear? Reconsidering the Late Minoan III Figures with

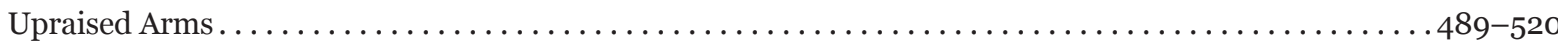

Gürtekin-Demir, R.G., Phrygian Aspects of Lydian Painted Pottery from Sardis . . . . . . . . . . . . 223-39

Harrell, K., The Fallen and Their Swords: A New Explanation for the Rise of the Shaft Graves $\ldots \ldots \ldots \ldots \ldots .17$

Hayden. See Molloy et al.

Isaakidou. See Molloy et al.

Keller. See Corbett et al.

Khatchadourian, L., Empire in the Everyday: A Preliminary Report on the 2008-2011 Excavations at

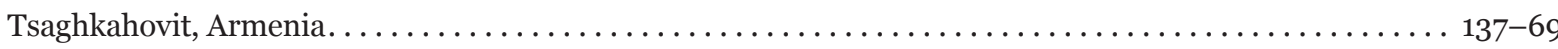

Kiernan, P., The Bronze Mice of Apollo Smintheus $\ldots \ldots \ldots \ldots \ldots \ldots \ldots \ldots \ldots \ldots \ldots \ldots \ldots \ldots \ldots$

Klontza-Jaklova. See Molloy et al.

Kotzamani. See Molloy et al.

Larsson. See Molloy et al.

Leon. See Smith and Leon.

Luley, B.P., Cooking, Class, and Colonial Transformations in Roman Mediterranean France. . . . . . . . . 33-60

Maran, J., and A. Van de Moortel, A Horse-Bridle Piece with Carpatho-Danubian Connections from Late

Helladic I Mitrou and the Emergence of a Warlike Elite in Greece During the Shaft Grave Period . . . . 529-48

Martinez-Sève, L., The Spatial Organization of Ai Khanoum, a Greek City in Afghanistan . . . . . . . . . . 267-83

Milić. See Molloy et al.

Mogetta, M., and J.A. Becker, Archaeological Research at Gabii, Italy: The Gabii Project Excavations,

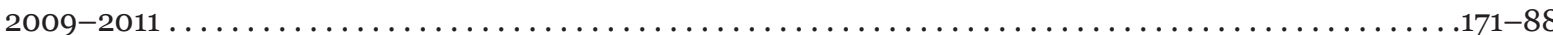

Published online October 2014 American Journal of Archaeology 118.4 
Molloy, B., J. Day, S. Bridgford, V. Isaakidou, E. Nodarou, G. Kotzamani, M. Milić, T. Carter, P. Westlake, V. Klontza-Jaklova, E. Larsson, and B.J. Hayden, Life and Death of a Bronze Age House: Excavation of Early Minoan I Levels at Priniatikos Pyrgos . . . . . . . . . . . . . . . . . . . . . . $307-58$

Nodarou. See Molloy et al.

Oakley, J.H., Greek Children: Three New Iconographic Studies $\ldots \ldots \ldots \ldots \ldots \ldots \ldots \ldots \ldots \ldots \ldots \ldots$

Öğ̈̈ş, E., Columnar Sarcophagi from Aphrodisias: Elite Emulation in the Greek East. . . . . . . . . . . . 113-36

Pantou, P.A., An Architectural Perspective on Social Change and Ideology in Early Mycenaean Greece . . . . .369-400

Pope, S., and P. Schultz, The Chryselephantine Doors of the Parthenon . . . . . . . . . . . . . . . .

Porter. See Corbett et al.

Privitera, S., Long-Term Grain Storage and Political Economy in Bronze Age Crete: Contextualizing Ayia

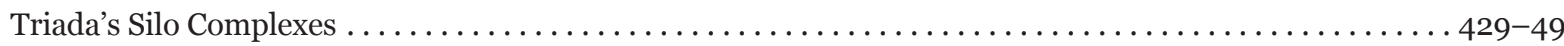

Schultz. See Pope and Schultz.

Scopacasa, R., Gender and Ritual in Ancient Italy: A Quantitative Approach to Grave Goods and Skeletal

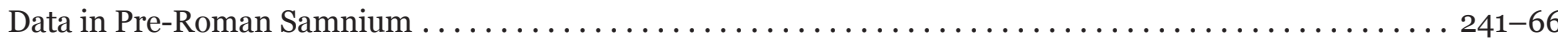

Smith, A.T., and J.F. Leon, Divination and Sovereignty: The Late Bronze Age Shrines at Gegharot,

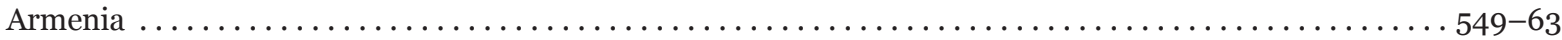

Stone, D.L., Africa in the Roman Empire: Connectivity, the Economy, and Artificial Port Structures .......565-600 Tuttle. See Corbett et al.

Ussishkin. See Adams et al.

Van de Moortel. See Maran and Van de Moortel.

Vavouranakis, G., Funerary Pithoi in Bronze Age Crete: Their Introduction and Significance at the Threshold of Minoan Palatial Society . . . . . . . . . . . . . . . . . . . . . . . . . . . . . . . . 197-222

Westlake. See Molloy et al.

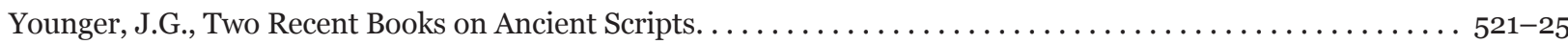

\section{ONLINE ONLY (open access at www.ajaonline.org)}

\section{Supplementary Content}

Andrews, M.M., Image Gallery: A Domus in the Subura of Rome from the Republic Through Late Antiquity Blackwell, N.G., Image Gallery: Making the Lion Gate Relief at Mycenae: Tool Marks and Foreign Influence Corbett, G.J., D.R. Keller, B.A. Porter, and C.A. Tuttle, Image Gallery: Archaeology in Jordan, 2012 and 2013 Seasons Cosmopoulos, M.B., Image Gallery: Cult, Continuity, and Social Memory: Mycenaean Eleusis and the Transition to the Early Iron Age

Mogetta, M., and J.A. Becker, Image Gallery: Archaeological Research at Gabii, Italy: The Gabii Project Excavations, 2009-2011

Molloy, B., J. Day, S. Bridgford, V. Isaakidou, E. Nodarou, G. Kotzamani, M. Milić, T. Carter, P. Westlake, V. KlontzaJaklova, E. Larsson, and B.J. Hayden, Appendix: Life and Death of a Bronze Age House: Excavation of Early Minoan I Levels at Priniatikos Pyrgos 


\section{Book Reviews}

Ahrens, A., Rev. of Killebrew and Lehmann, eds., The Philistines and Other "Sea Peoples" in Text and Archaeology Allen, S.E., Rev. of Sampson, ed., The Cave of the Cyclops: Mesolithic and Neolithic Networks in the Northern Aegean, Greece. Vol. 2, Bone Tool Industries, Dietary Resources and the Paleoenvironment, and Archaeometrical Studies

Bell, S., Rev. of Koch and Baratte, eds., Akten des Symposiums "Sarkophage der Römischen Kaiserzeit: Produktion in den Zentren-Kopien in den Provinzen"/"Les sarcophages romains: Centres et périphéries," Paris, 2.-5. November 2005

- Rev. of Mander, Portraits of Children on Roman Funerary Monuments

Blackwell, N.G., Rev. of Kassianidou and Papasavvas, eds., Eastern Mediterranean Metallurgy and Metalwork in the Second Millennium BC: A Conference in Honour of James D. Muhly, Nicosia, 10th-11th October 2009

Bonney, E.M., Rev. of Abramiuk, The Foundations of Cognitive Archaeology

Bowes, K., Rev. of Attema and Schörner, eds., Comparative Issues in the Archaeology of the Roman Rural Landscape: Site Classification Between Survey, Excavation and Historical Categories

Boyes, P., Rev. of Aubet, Commerce and Colonization in the Ancient Near East

Burke, A.A., Rev. of Seger, Gezer VII: The Middle Bronze and Later Fortifications in Fields II, IV, and VIII

Caraher, W., Rev. of Lapadula, The Chora of Metaponto 4: The Late Roman Farmhouse at San Biagio

Cherry, J.F., Rev. of Ratté and De Staebler, eds., The Aphrodisias Regional Survey

Chovanec, Z., Rev. of Matisoo-Smith and Horsburgh, DNA for Archaeologists

Christie, N., Rev. of Jacobs, Aesthetic Maintenance of Civic Space: The "Classical" City from the 4th to the 7 th c. AD

Cline, E.H., Rev. of Abt, American Egyptologist: The Life of James Henry Breasted and the Creation of His Oriental Institute

Cunningham-Bryant, A., Rev. of Török, Hellenizing Art in Ancient Nubia 300 B.C.-AD 250 and Its Egyptian Models: A Study in "Acculturation"

Draycott, C.M., Rev. of Dusinberre, Empire, Authority, and Autonomy in Achaemenid Anatolia

Emberling, G., Rev. of Harmanşah, Cities and the Shaping of Memory in the Ancient Near East

Emerson, T.E., Rev. of Olsen, Shanks, Webmoor, and Witmore, Archaeology: The Discipline of Things

Fagan, G.G., Rev. of Lucore and Trümper, eds., Greek Baths and Bathing Culture: New Discoveries and Approaches

Foss, P.W., Rev. of Ellis, ed., The Making of Pompeii: Studies in the History and Urban Development of an Ancient Town

Galanakis, Y., Rev. of Privitera, Principi, Pelasgi e pescatori: L'Attica nella Tarda Età del bronzo

Gessert, G.S., Rev. of Bocherens, ed., Nani in Festa: Iconografia, religion e politica a Ostia durante il secondo triumvirato

Gilmour, G., Rev. of Master, The Oxford Encyclopedia of the Bible and Archaeology. 2 vols.

Gordon, J.M., Rev. of Fujii, Imperial Cult and Imperial Representation in Roman Cyprus

Graells i Fabregat, R., Rev. of Aldrete, Bartell, and Aldrete, Reconstructing Ancient Linen Body Armor: Unraveling the Linothorax Mystery

Hadji, A., Rev. of Knapp, The Archaeology of Cyprus: From Earliest Prehistory Through the Bronze Age

Hirschfeld, N., Rev. of Steele, Syllabic Writing on Cyprus and Its Context

Höflmayer, F., Rev. of Iamoni, The Late MBA and LBA Pottery Horizons at Qatna: Innovation and Conservation in the Ceramic Tradition of a Regional Capital and the Implications for Second Millennium Syrian Chronology

- Rev. of Martin, Egyptian-Type Pottery in the Late Bronze Age Southern Levant

— Rev. of Peltenburg, ed., Associated Regional Chronologies for the Ancient Near East and the Eastern Mediterranean: Cyprus 
Hritz, C., Rev. of Stronach and Mousavi, eds., Ancient Iran from the Air

Hrychuk Kontokosta, A., Rev. of Anderson, Jr., Roman Architecture in Provence

Ivleva, T., Rev. of Hemelrijk and Woolf, eds., Women and the Roman City in the Latin West

— - Rev. of Kristensen and Poulsen, eds., Ateliers and Artisans in Roman Art and Archaeology

Jacobs, I., Rev. of Dally and Ratté, eds., Archaeology and the Cities of Asia Minor in Late Antiquity

Kamlah, J., Rev. of Dever, The Lives of Ordinary People in Ancient Israel: Where Archaeology and the Bible Intersect

Kelder, J.M., Rev. of Steel, Materiality and Consumption in the Bronze Age Mediterranean

Kellum, B., Rev. of Trimble, Women and Visual Replication in Roman Imperial Art and Culture

Kiernan, P., Rev. of Madigan, The Ceremonial Sculptures of the Roman Gods

Klein, N.L., Rev. of Verdan, Le sanctuaire d'Apollon Daphnéphoros à l'époque géométrique. 2 vols.

Kleiner, F.S., Rev. of Zanker and Ewald (Slater, trans.), Living with Myths: The Imagery of Roman Sarcophagi

Kosso, C., Rev. of Alberti and Sabatini, eds., Exchange Networks and Local Transformations: Interaction and Local Change in Europe and the Mediterranean from the Bronze Age to the Iron Age

Kuniholm, P.I., Rev. of Çilingiroğlu and Sagona, eds., Anatolian Iron Ages 7: Proceedings of the Seventh Anatolian Iron Ages Colloquium Held at Edirne, 19-24 April 2010

Langford, J., Rev. of Manders, Coining Images of Power: Patterns in the Representation of Roman Emperors on Imperial Coinage, A.D. 193-284

Lantzas, K., Rev. of Nakassis, Individuals and Society in Mycenaean Pylos

Lomas, K., Rev. of Laurence, Esmonde-Cleary, and Sears, The City in the Roman West, c.25o BC-c.AD 250

Lynch, K.M., Rev. of Pala, Acropoli di Atene: Un microcosmo della produzione e distribuzione della ceramica attica

McDowell-Loudan, E.E., Rev. of Lazrus and Barker, eds., All the King's Horses: Essays on the Impact of Looting and the Illicit Antiquities Trade on Our Knowledge of the Past

Moore, M.B., Rev. of Saripanidi, Corpus Vasorum Antiquorum. Greece 13. Thessaloniki: Aristotle University, Cast Museum

—, Rev. of Serbeti, Corpus Vasorum Antiquorum. Greece 12. Athens, National Museum 6: Attic Black-Figure and Six's Technique Lekythoi

Müller, M., Rev. of Yasur-Landau, Ebeling, and Mazow, eds., Household Archaeology in Ancient Israel and Beyond

Mylonopoulos, J., Rev. of Mitsopoulos-Leon, Das Heiligtum der Artemis Hemera in Lousoi: Kleinfunde aus den Grabungen 1986-2000

O’Donoghue, E., Rev. of Bellelli, ed., Le origini degli Etruschi: Storia, archeologia, antropologia

Papadopoulos, J.K., Rev. of Valavanis (Doumas, trans.), The Acropolis Through Its Museum: Wandering Among the Monuments of the Sacred Rock and the Great Achievements

Richard, J., Rev. of Robinson, Histories of Peirene: A Corinthian Fountain in Three Millennia

Rogers, A., Rev. of Mithen, Thirst: Water and Power in the Ancient World

Rohl, D.J., Rev. of Christie and Augenti, eds., Vrbes extinctae: Archaeologies of Abandoned Classical Towns

Ruscillo, D., Rev. of Russell, Social Zooarchaeology: Humans and Animals in Prehistory

Sarris, A., Rev. of Schmidt, Earth Resistance for Archaeologists

Saunders, D., Rev. of Mommsen, Corpus Vasorum Antiquorum. Germany 94. Berlin 14: Attisch schwarzfigurige Amphoren

Scotton, P.D., Rev. of Dubbini, Dei nello spazio degli uomini: I culti dell'agora e la costruzione di Corinto arcaica

Shipley, L., Rev. of Cascino, Di Giuseppe, and Patterson, eds., Veii, the Historical Topography of the Ancient City: A

Restudy of John Ward-Perkins's Survey

Slane, K. Warner, Rev. of McKenzie-Clark, Vesuvian Sigillata at Pompeii

Published online October 2014 American Journal of Archaeology 118.4

DOI: 10.3764/ajaonline1184.Index

Published by the Archaeological Institute of America 
Stewart, A., Rev. of Smith, The Marble Reliefs from the Julio-Claudian Sebasteion

Stewart, S.M., Rev. of Lawall and Lund, eds., Pottery in the Archaeological Record: Greece and Beyond. Acts of the

International Colloquium Held at the Danish and Canadian Institutes in Athens, June 2O-22, 2008

Stoddart, S., Rev. of Attema, Burgers, and van Leusen, Regional Pathways to Complexity: Settlement and Land-Use

Dynamics in Early Italy from the Bronze Age to the Republican Period

Stronk, J.P., Rev. of Dodson, Afterglow of Empire: Egypt from the Fall of the New Kingdom to the Saite Renaissance

Sumi, G.S., Rev. of Spalinger and Armstrong, eds., Rituals of Triumph in the Mediterranean World

Swan, G. Middleton, Rev. of Belozerskaya, Medusa's Gaze: The Extraordinary Journey of the Tazza Farnese

Tuck, A., Rev. of Turfa, ed., The Etruscan World

Viitanen, E.-M., Rev. of Anguissola, ed., Privata Luxuria: Towards an Archaeology of Intimacy. Pompeii and

Beyond. International Workshop Center for Advanced Studies, Ludwig-Maximilians-Universität München (24-25 March 2011)

Voyatzis, M.E., Rev. of Papapostolou, Early Thermos: New Excavations 1992-2003

Walsh, J. St. P., Rev. of Thomasen, Rathje, and Bøggild Johannsen, eds., Vessels and Variety: New Aspects of Ancient Pottery

Weiberg, E., Rev. of Banks, Lerna, A Preclassical Site in the Argolid. Vol. 6, The Settlement and Architecture of Lerna IV

Willekes, C., Rev. of O'Daniel Cantrell, The Horsemen of Israel: Horses and Chariotry in Monarchic Israel (NinthEighth Centuries B.C.E.)

Yasur-Landau, A., Rev. of Wachsmann, The Gurob Ship-Cart Model and Its Mediterranean Context 